Categoria

Trabalho Acadêmico\Resumo Expandido

Titulo do Trabalho

\title{
A BARAÚNA (SCHINOPESIS BRASILIENSIS) NA TRAMA RURAL DO MUNICÍPIO DE CALÇADO - PERNAMBUCO
}

Nome do Autor (a) Principal

Raí Vinicius Santos

Nome (s) do Orientador (a):

Maria Betânia Moreira Amador

Instituição ou Empresa

UPE/CAMPUS GARANHUNS

Instituição (s) de Fomento

PFA/PIBIC/CNPq

E-mail de contato

raí.2vinicius@hotmail.com

Palavras-chave:

Baraúna. Sistemismo. Calçado-PE.

1 INTRODUÇÃO

O pensamento complexo na questão ambiental, trazida por Edgar Morin, trouxe uma nova reflexão sobre essa questão deixando de ser apenas natural e passando a se relacionar à social, perfazendo novas discussões e o surgimento de novos paradigmas 
em várias áreas do conhecimento, além do conceito de uma organização sistêmica quebrando, assim, preconceitos e tabus que pudessem existir sobre o meio ambiente e o uso dessa expressão, questão essa que abriu as portas ao despertar ecológico, trazido por Alfredo Pena-Vega, que, calcado nas concepções complexas do próprio Edgar Morin, escreveu sobre as intrínsecas relações de dependências e independências do homem e do meio como integrante de um sistema, e, sem esquecer contudo da questão da preservação do meio ambiente que se tornou de grande foco devido aos muitos desequilíbrios ecológicos, respaldado também numa reorganização epistêmica colocada pelo Michel Foucault em 1966 como salientado por Pena-Vega em sua obra o Despertar Ecológico (2003), o que possibilitou novas visões sobre ecologia.

Essa visão de sistemas colocada para tornar o meio ambiente parte dinâmica relacionada à ação humana foi tida como principal método que evidenciasse justamente essa relação que existe entre o natural e o social, pois na evolução do pensamento geográfico, desde sua sistematização, com Humboldt que era naturalista e Ritter que descrevia as organizações espaciais dos homens sobre os diferentes lugares, atrelaram essas vertentes porém com dissociações que ao mesmo tempo as separavam. Mais tarde, Ratzel propôs uma visão do determinismo dos lugares sobre o homem, contrapondo a isso, La Blache concebia as possibilidades que o homem poderia ter sobre o meio, e a separação entre elementos físico-naturais e elementos humano-sociais, no entanto nenhuma dessas concepções conseguiu interrelacionar o homem com o meio natural.

Seguindo a discussão do pensamento complexo e a ideia de sistemas, é notável que nem o método positivista, que não conseguia associar a questão física à humana, nem o marxismo, que partia da crítica do homem e sua sociedade, foram capazes de conceber em seus estudos as relações complexas do meio ambiente, sendo a teoria de sistemas o principal método encarregado do estudo dessa área.

Ao se descobrir que o meio ambiente afirma as complexas interrelações entre o social e o natural, ambos em constante transformação, começam a surgir várias discussões no meio acadêmico e o aparecimento de muitos trabalhos que evidenciavam a problemática desse contexto, fazendo-se relevante uma ampla discussão que se integrasse em diversas áreas do saber. 


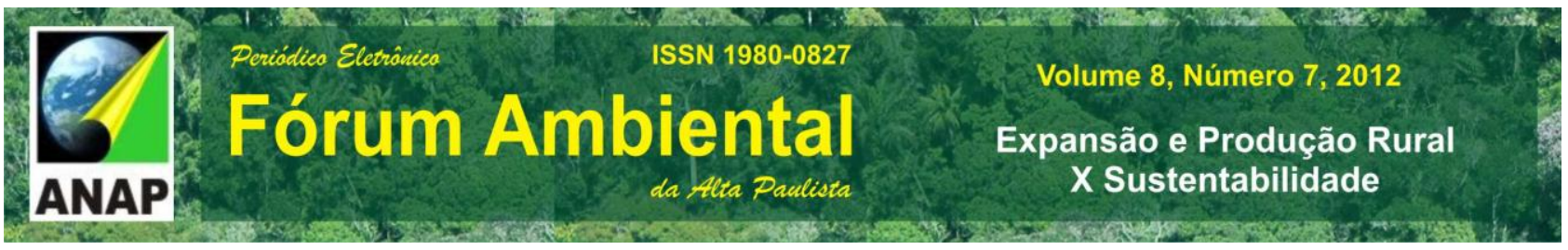

Trazendo essas concepções e discussões para a realidade do Nordeste brasileiro, da realidade do semiárido, e, podendo-se assim, adentrar no bioma caatinga, usa-se a percepção paisagística para identificar a relevância do estudo sobre a Braúna, também denominada baraúna, uma espécie nobre da caatinga que, devido a grande variedade na sua utilização, levou a uma exploração excessiva e, quase sem reposição. Seguiu-se assim, ao quase esgotamento das reservas dessa espécie, sendo hoje considerada em perigo imediato de extinção, principalmente no nordeste do Brasil.

Assim, o projeto que se inicia no âmbito do PFA/PIBIC/CNPq aborda como tema a relação natural e social da Schinopesis brasiliensis (Braúna) com o meio rural e urbano numa perspectiva de paisagem verde no município de Calçado- PE, trabalho que se desenvolve num contexto mais amplo de estudo do verde urbano e rural do Agreste Meridional de Pernambuco. Logo, verificou-se a existência dessa árvore em Calçado - PE, levando a discussão sobre a sua importância para a natureza e para sociedade numa perspectiva de paisagem verde no espaço rural do referido município. Assim, a elaboração da pesquisa está objetivando a análise da função da Braúna sob a visão natural e social num contexto sistêmico atrelado a questões verdes da paisagem. Esta pesquisa justifica-se em função da importância da compreensão dessa espécie do sertão para, assim, poder-se contribuir para sua melhor preservação. A metodologia está se materializando pelo levantamento bibliográfico, bem como a ida a campo para observação, ainda será feito um questionário e/ou entrevista informal aos moradores da região, como também o uso de máquina fotográfica para tomada de algumas fotos. $\mathrm{Na}$ perspectiva da percepção considerar-se-á o lado afetivo e de apego ao lugar, e, a braúna como parte pertencente a esse contexto levando-se assim à assimilação de sua importância para os indivíduos e para a própria dinâmica natural do espaço de forma integrada.

\section{OBJETIVO GERAL}

Analisar a Schinopesis brasiliensis (Braúna) em sua funcionalidade, tanto natural, quanto social, inserida na área rural do município de Calçado-PE, num contexto sistêmico, atrelado a questões verdes da paisagem. 


\section{OBJETIVOS ESPECÍFICOS}

- Localizar as árvores e a maior concentração dessa espécie no município de Calçado-PE;

- Observar sua utilização, tanto num contexto natural, quanto social;

- Relacionar a Baraúna à complexidade ambiental que a envolve;

- Refletir sobre sua importância para a zona rural do município.

\section{METODOLOGIA}

O estudo será realizado no município de Calçado-PE, localizado no Agreste Meridional, fazendo parte do Semiárido pernambucano, distante a $200,1 \mathrm{Km}^{2}$ do Recife, destaca-se pela produção agrícola de feijão. A temperatura média anual é de $22,1^{\circ} \mathrm{C}$.

A metodologia materializa-se pelo levantamento bibliográfico, bem como a ida a campo para observação. Mostrando-se necessário a interdisciplinaridade a questões expostas no projeto. Haverá também questionário ou entrevista informal a moradores próximos ao objeto de estudo, como também o uso de máquina fotográfica para tomada de algumas fotos.

\section{RESULTADO (S)}

Têm-se como resultado parcial que a ocorrência de forma concentrada da Braúna no município de Calçado-PE encontra-se no Sítio Pitombeira, no qual se acredita existir um ambiente propício ao seu desenvolvimento. Também, através de informações colhidas no local, propriedades vizinhas, até recentemente, abatiam essas árvores e as vendiam por $\mathrm{R} \$ 50,00$ para madeireiras da região, visto tratar-se de madeira própria para fabricação de mourão de porteiras, aviamento de casas de farinha, principalmente na prensa de mão de pilão, cabos de ferramentas, macetas e esquadrias, portais soleiras, pontaletes fréxais de vão e vigamentos. 


\section{CONSIDERAÇÕES FINAIS}

A abordagem levantada apresenta um viés que coloca em evidência o fato da braúna ser uma árvore essencial na caatinga e no semiárido nordestino, apresentando características únicas e que, infelizmente, por utilização desregrada está causando uma carência paisagística na zona rural e sendo quase inexistente na área urbana do município em estudo. E, a partir dos colóquios expostos agregar essa árvore nobre da caatinga aos paradigmas da natureza pautados na teoria de sistema que surge como um dos principais métodos utilizados na análise ambiental.

\section{REFERÊNCIAS}

ALBUQUERQUE, U. P. de; ANDRADE, L. de H. C. Conhecimento botânico tradicional e conservação em uma área de Caatinga no Estado de Pernambuco, Nordeste do Brasil. Acta Botanica Brasilica, São Paulo, v. 16, n. 3, p. 273-285, 2002.

ALBUQUERQUE, U. P. de; ANDRADE, L. de H. C.; SILVA, A. C. O. de. Use of plant resources in a seasonal dry forest (Northeastern Brazil). Acta Botanica Brasilica, São Paulo, v. 19, n. 1, p. 27-38, 2005.

AMADOR, Maria Betânia Moreira. Sistemismo e sustentabilidade: questão interdisciplinar. São Paulo: Scortecci, 2011.

PENA-VEGA, Alfredo; O Despertar Ecológico: Edgar Morin e a ecologia complexa. Tradução de Renato Cavalheira e Elimar Pinheiro do Nascimento- Rio de Janeiro: Garamond, 2003.

FALCÃO SOBRINHO, José; FALCÃO, Cleire Lima Costa. Geografia Física: a natureza na pesquisa e no ensino. Rio de Janeiro. TMAISOITO. 2008. 